Article

\title{
Processing Dross from Hot-Dip Galvanizing by Chlorination Roasting
}

\author{
Nurlan Kalievich Dosmukhamedov ${ }^{1, *}$, Arkady Kaplan ${ }^{2}$, Erzhan Esenbaiuly Zholdasbay ${ }^{1}$, \\ Gulzada Myngyshkyzy Koishina ${ }^{1}{ }^{10}$, Yeleussiz Bolatovich Tazhiev ${ }^{1}$, Aidar Argyn ${ }^{1}$, \\ Yerzhan Itemenovich Kuldeyev ${ }^{1}$ and Valery Kaplan ${ }^{3}$ (D)
}

Citation: Dosmukhamedov, N.K.; Kaplan, A.; Zholdasbay, E.E.; Koishina, G.M.; Tazhiev, Y.B.; Argyn,

A.; Kuldeyev, Y.I.; Kaplan, V. Processing Dross from Hot-Dip Galvanizing by Chlorination Roasting. Sustainability 2021, 13, 12530. https://doi.org/10.3390/ su132212530

Academic Editors: Rita Khanna, Yury Konyukhov and Igor Burmistrov

Received: 21 September 2021 Accepted: 2 November 2021 Published: 12 November 2021

Publisher's Note: MDPI stays neutral with regard to jurisdictional claims in published maps and institutional affiliations.

Copyright: (C) 2021 by the authors. Licensee MDPI, Basel, Switzerland. This article is an open access article distributed under the terms and conditions of the Creative Commons Attribution (CC BY) license (https:// creativecommons.org/licenses/by/ $4.0 /$ )
1 Department of Metallurgy and Mineral Processing, Satbayev University, Almaty 050000, Kazakhstan; zhte@mail.ru (E.E.Z.); gulzada.koishina@mail.ru (G.M.K.); eleusiz_t1990@mail.ru (Y.B.T.); aidarargyn@gmail.com (A.A.); e.kuldeyev@satbayev.university (Y.I.K.)

2 Arvak Tech. LLC, Rehovot 76000-76878, Israel; arkadyc@gmail.com

3 Weizmann Institute of Science, Rehovot 76000-76878, Israel; valery.kaplan@weizmann.ac.il

* Correspondence: nurdos@bk.ru

\begin{abstract}
Dross from hot-dip galvanizing is an important source of pure zinc ingots and zinc oxide for use as mineral additives in animal and poultry feed. Thermodynamic calculations have shown the possibility of solving the issue of dross processing by roasting using $\mathrm{CaCl}_{2}$ and $\mathrm{NH}_{4} \mathrm{Cl}$. The influence of the consumption of chlorinating reagents, the roasting temperature on the degree of sublimation of $\mathrm{Pb}, \mathrm{Fe}, \mathrm{Ni}, \mathrm{Cu}$ and $\mathrm{Cd}$ has been investigated. It has been shown that the best results are achieved when roasting the dross with the simultaneous use of $\mathrm{CaCl}_{2}$ and $\mathrm{NH}_{4} \mathrm{Cl}$ in amounts of 6 and $15 \%$ by weight of the feed material. The optimal roasting parameters were established: $\mathrm{T}=1000{ }^{\circ} \mathrm{C}$, duration $-60 \mathrm{~min}$, air flow $-0.1 \mathrm{~L} / \mathrm{min}$. Recovered pure zinc oxide composition (\%) was: $0.05 \mathrm{~Pb}, 0.15 \mathrm{Fe}, 0.06 \mathrm{Ni}, 0.003 \mathrm{Cu}$ and $0.001 \mathrm{Cd}$. The degree of sublimation of copper, nickel and iron chlorides was $\sim 75 \%$, with lead and cadmium at $90-98 \%$ of their initial amount in the dross.
\end{abstract}

Keywords: dross; roasting; calcium chloride; ammonium chloride; impurities; sublimation; extraction; zinc; zinc oxide

\section{Introduction}

World zinc production is showing a slight increase, with consumption reaching $\sim 14$ million tons per year [1,2]. The main uses of zinc include the processes of galvanizing products. Hot-dip galvanized steel accounts for $50 \%$ of global zinc consumption [3]. High prices for zinc, which make up the main part of the cost of galvanizing, require its economical use and disposal of its waste, in particular, dross. The amount of dross during galvanizing is around 0.5 to $3.5 \%$ of the mass of the treated products. Despite the fact that, in terms of its composition, dross mainly consists of zinc oxide, $30-40 \%$ of metallic zinc remains in it [4,5]. Zinc ash represents 12 to $15 \%$ of the total amount of zinc used for piece hot galvanizing (leaching of zinc from zinc ash originating from hot-dip galvanizing) [5]. It is estimated that treatment of one ton of steel generates about $10 \mathrm{~kg}$ of the zinc dross and $9 \mathrm{~kg}$ of the zinc ash, giving a potential total zinc stream of 15-18 kg to recover [6]. Statistical data shows that every year in the European Union about $19 \mathrm{~kg}$ of steel per inhabitant is galvanized. For comparison, the average values calculated per inhabitant reach $12 \mathrm{~kg}$ in Poland, $26 \mathrm{~kg}$ in Belgium and $32 \mathrm{~kg}$ in Austria [7]. The Hot-dip Galvanized Steel Market report forecasts continuous increase in global production of galvanized steel at a compound annual growth rate of $5.1 \%$ in the period of 2019-2025 [8]. The complex chemical composition of the dross makes it difficult for further usage. Its main processing in practice is about the recovering of the metallic zinc.

Due to its poor quality, dross is not a marketable product and, in most cases, is reused in the process of galvanizing products. A significant content of lead and other impurity metals 
remain in the oxide part of the dross, so it has limited further applications. This problem is an important issue for enterprises in Kazakhstan, where steel products are galvanized. Due to the development of the construction industry, the demand for a wide range of galvanized steel products (pipes, channels, squares, wire, etc.) has sharply increased in the republic. The increase in the capacity of enterprises for the hot-dip galvanizing of steel products has led to large volumes of waste dross starting to accumulate, with storage occupying large areas. Further use and processing of dross is constrained by the increased content of $\mathrm{Pb}, \mathrm{Fe}, \mathrm{Cu}$ and other impurities in it, as well as the lack of rational processing technology.

Currently, in practice, pyrometallurgical methods of dross processing to obtain metallic zinc are widely used [9-15]. In recent years, hydrometallurgical methods have also been developing [1-5]. The most common way of dross processing is their heating in cylindrical drums or retorts of various designs to a temperature higher than the melting point of zinc [9]. The disadvantage of these methods is the lack of sealing the internal volume of the drum. The second significant drawback is the absence of direct contact of the walls of the heated combustion chamber with the raw material loaded into the drum.

The patented pyrometallurgical methods of dross processing with the use of various reagents (acids, alkaline methods, the addition of sodium and aluminum fluorides, etc.) have become widespread [10-15]. The main disadvantages of these works include: the laboriousness of the separation of the metal fraction; the formation of a large volume of wastewater requiring additional purification and evaporation to obtain zinc chloride; energy costs associated with the use of additional equipment; and an increase in the number of workers. One of the most effective methods for dross processing can be the preliminary separation of the metal and oxide parts of the dross, with further separate processing of each of them [16]. The metal part is melted in an induction furnace under a layer of ammonium chloride and charcoal. Metallic zinc is obtained from the metal part with the composition (\%): $95.9 \mathrm{Zn}, 1.54 \mathrm{~Pb}, 0.9 \mathrm{Fe}$ and $0.4 \mathrm{Cu}$. The oxide part of the dross is subjected to roasting at $800-900{ }^{\circ} \mathrm{C}$ and zinc oxide is obtained, which is used for the preparation of whitewash. The elevated content of lead $(1.2 \%)$ and iron $(0.95 \%)$ in the oxide part of the dross does not allow obtaining high quality zinc oxide white paint.

Despite the indicated disadvantages, the approach proposed in [16] for the preliminary separation of the metal and oxide parts of the dross, with further separate processing of each of them, seems to be quite effective. At the same time, if the metal part can be used as a material for secondary use in galvanizing, then investigating the ways to process the non-metallic, oxide part of the dross containing such impurities as $\mathrm{Pb}, \mathrm{Fe}, \mathrm{As}$ and $\mathrm{Sb}$ requires additional research. In this regard, the use of metal chlorination has a great interest for the processing of dross. Characteristics of metal chlorides, such as their low melting point, high volatility and solubility in water, make it possible to recover valuable metals from various wastes in the form of their chlorides $[17,18]$. In terms of the complexity of the formation of metal chlorides and the difference in their properties, metals can be selectively chlorinated and sublimated by controlling the reaction temperature and vapor pressure of the products participating in the reaction [19-21].

In practice, chlorine gas, hydrogen chloride and alkali metal chlorides are used as chlorinating reagents. The use of $\mathrm{CaCl}_{2}$, which has a high ability to chlorinate metals and has a rather low cost, has become widespread among them. This work presents the results of the reduction of impurity metals $\left(\mathrm{Pb}, \mathrm{Fe}\right.$, etc.) from the dross by its roasting with $\mathrm{CaCl}_{2}$ and $\mathrm{NH}_{4} \mathrm{Cl}$. The results of comprehensive investigation on the study of the influence of the consumption of chlorinating reagents and temperature on the behavior of $\mathrm{Pb}, \mathrm{Fe}, \mathrm{Ni}, \mathrm{Cu}$ and $\mathrm{Cd}$ under roasting conditions are presented. Based on thermodynamic calculations of the reactions of the interaction of metal impurities with $\mathrm{CaCl}_{2}$ and $\mathrm{NH}_{4} \mathrm{Cl}$, the possibility of obtaining pure metallic zinc and a mineral zinc additive $(\mathrm{ZnO})$ suitable for use in animal and poultry feed is shown.

The importance of the obtained results is about their application for the development of a reductive-chlorinating technology aimed at utilization of accumulated substandard wastes of the hot-dip galvanizing process, for the additional production of commercial zinc 
metal and pure zinc oxide. The technology improves the quality of the environment by reducing harmful emissions into the environment $(\mathrm{Pb}$, etc.), which fully meets the priority areas of scientific, technical and socioeconomic development of the Republic of Kazakhstan.

\section{Experimental Part}

- Experimental procedure

The initial sample of dross was crushed on a Cutting Mill SM 300 and subjected to sieve analysis with separation of the metal $\left(\mathrm{Zn}_{\text {met. }}\right)$ and oxide $(\mathrm{ZnO})$ fractions. The metal fraction in the amount of $50 \mathrm{~g}$ was melted in a high-temperature shaft furnace ( $\mathrm{SiC}$ heaters) at a heating rate of $10{ }^{\circ} \mathrm{C} / \mathrm{min}$ with the addition of $3 \% \mathrm{NH}_{4} \mathrm{Cl}$ to the initial sample. Once the specified melting time had elapsed, the crucible with the material was removed from the furnace, cooled, and metallic zinc was separated.

The oxide fraction of the dross was pre-mixed with different consumption of chlorinating reagents $\left(\mathrm{CaCl}_{2}, \mathrm{NH}_{4} \mathrm{Cl}\right)$, loaded into an aluminum oxide boat and roasted in a horizontal furnace at a given temperature in an air flow. The gases from the furnace were directed to a gas-cleaning bottle for absorption. After the required holding time had elapsed, the furnace was cooled in a stream of air, after which the crucible with the obtained material (cinder) was removed from the furnace and broken. The cinder was weighed and analyzed for the content of impurity metals.

- $\quad$ Research methods

A SiC heating furnace was used as an experimental equipment for melting the metal fraction of dross. For roasting of oxide fraction of dross, Nabertherm RT 50-250/12 horizontal electric furnace with temperature controller B410 was used. For melting and for roasting, alumina crucibles and alumina boats $(120 \times 60 \times 20 \mathrm{~mm})$, respectively, were used as a container for loading the feed materials. The airflow rate during roasting of the oxide fraction of dross with $\mathrm{CaCl}_{2}$ and $\mathrm{NH}_{4} \mathrm{Cl}$ was monitored with RM-GC 0.04 rotameter.

Preparation of the samples for chemical analysis was carried out as follows: $10 \mathrm{mg}$ of the material was dissolved in $65 \%$ (vol.) nitric acid and then analyzed. Material composition was characterized using an atomic absorption spectrophotometer equipped with a graphite combustion chamber (Perkin Elmer 5100). Powder X-ray diffraction (XRD) was performed on an Ultima III diffractometer (Rigaku Corporation, Japan) with quantitative phase analysis accomplished using Jade_10 (MDI, Cal.) software and the ICSD database and energy-dispersive $\mathrm{X}$-ray fluorescence spectroscopy was performed on a LEO Supra scanning electron microscope (SEM).

Each sample obtained after the experiments was subjected to the elemental composition twice. The final elemental composition was determined based on the average value obtained from the results of two independent measurements. For a better understanding of the mechanism of roasting, a detailed thermodynamic analysis of the interaction of dross components with chlorinating reagents $\left(\mathrm{CaCl}_{2}\right.$ and $\left.\mathrm{NH}_{4} \mathrm{Cl}\right)$ was carried out.

- $\quad$ Feed material

The dross obtained after galvanizing steel pipes at the plant in Karaganda city was used as a feed material. The initial dross after grinding was subjected to sieve analysis and divided into classes. The results of the classification of the dross and the yields of the products of each class are shown in Table 1.

Three large fractions of dross are a metallic phase, consisting of zinc beads of different sizes with a small content of impurities. The results of XRD analysis and the phase composition of the fine fraction of the sample ( -35 mesh) showed that it is mainly represented by the oxidized phase $(\mathrm{ZnO})$ with small impregnations of metal in the form of a zinc-iron alloy, the surface of which is covered with a zinc oxide film (Figure 1). As the results of the phase composition of the fine oxidized dross fraction (Figure 1) show, it consists of $97.6 \%$ $\mathrm{ZnO}$ and $2.4 \% \mathrm{Zn}-\mathrm{Fe}$ alloy. Other impurity metals $(\mathrm{Pb}, \mathrm{Cu}, \mathrm{Cd})$ are not displayed in the $\mathrm{X}$-ray diffraction pattern due to the low content. 
Table 1. Results of sieve analysis and product yield by class.

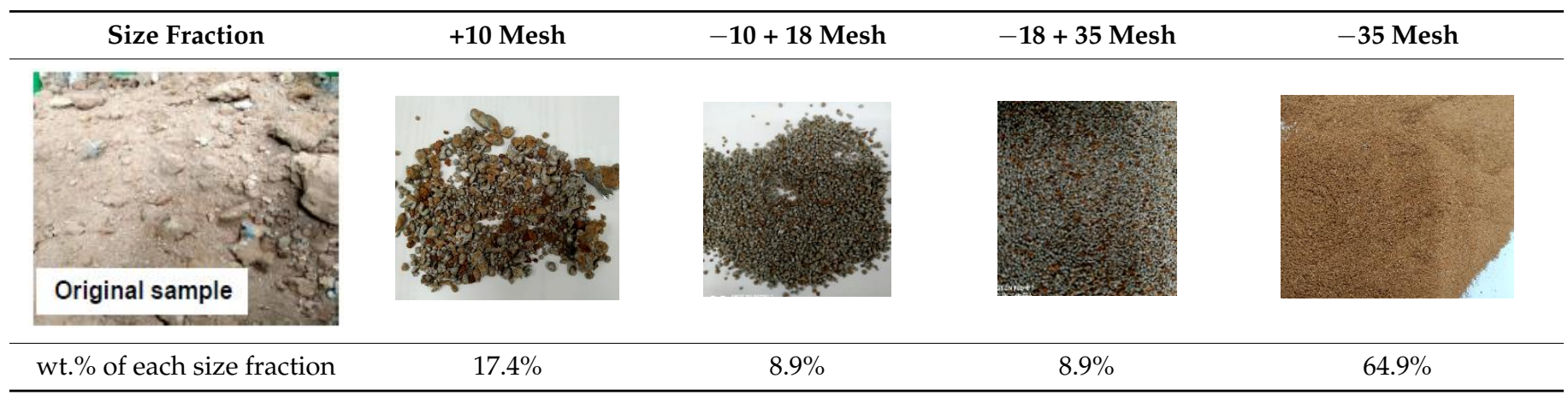

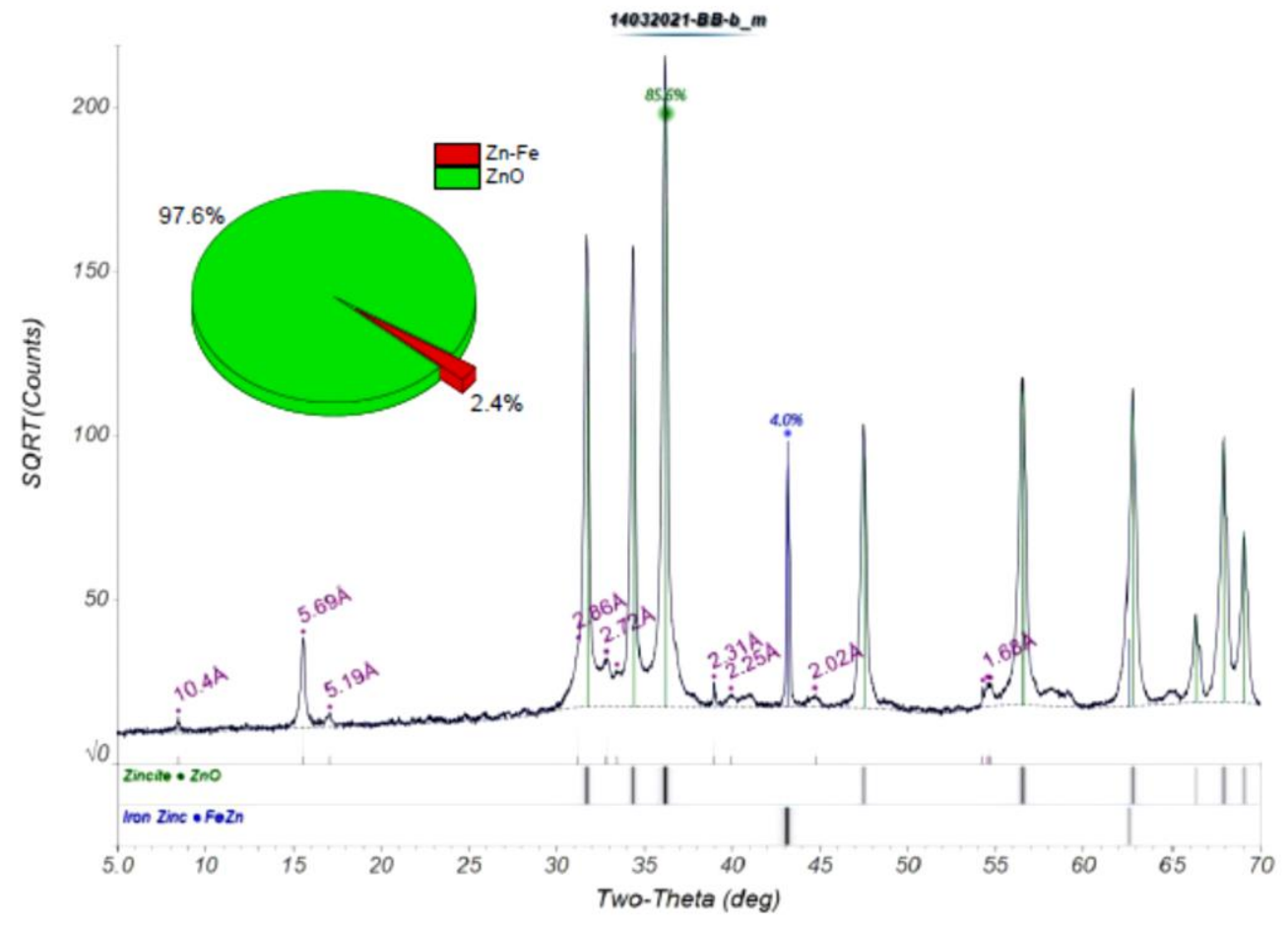

Figure 1. X-ray diffraction pattern and phase composition of the oxidized fraction.

From the results of SEM analyses, it can be seen (Figure 2) that, in the fine oxidized fraction, there are many particles of irregular shape. Two typical forms (point 1-dark area; point 2-pronounced white areas) can be seen: in the first corresponding area, the main components in the form of $\mathrm{ZnO}$ are represented; in the second area is an alloy of zinc and iron. Elemental EDS analysis shows a zinc content of $93.38 \%$, which is in good agreement with the result of the phase composition established by the XRD method (Figure 1).

The results of the chemical analysis of the oxide fraction presented in Table 2 shows the presence of such impurities as $\mathrm{Pb}, \mathrm{Ni}, \mathrm{Cu}$ and $\mathrm{Cd}$.

Table 2. Impurities content in the oxidized fraction.

\begin{tabular}{cccccc}
\hline Element & $\mathbf{P b}$ & $\mathbf{F e}$ & $\mathbf{N i}$ & $\mathbf{C u}$ & $\mathbf{C d}$ \\
\hline Content, wt.\% & 0.34 & 0.54 & 0.3 & 0.06 & 0.002 \\
\hline
\end{tabular}




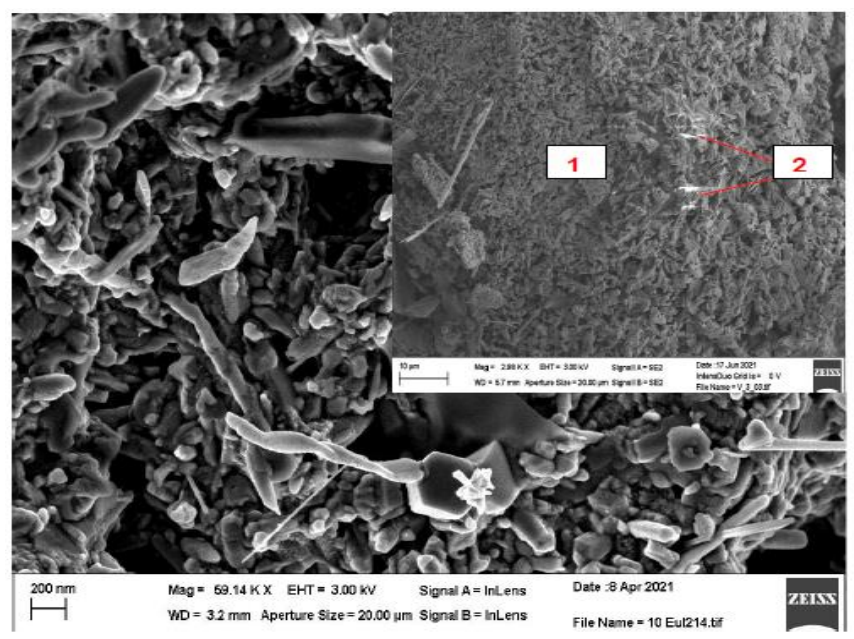

(a)
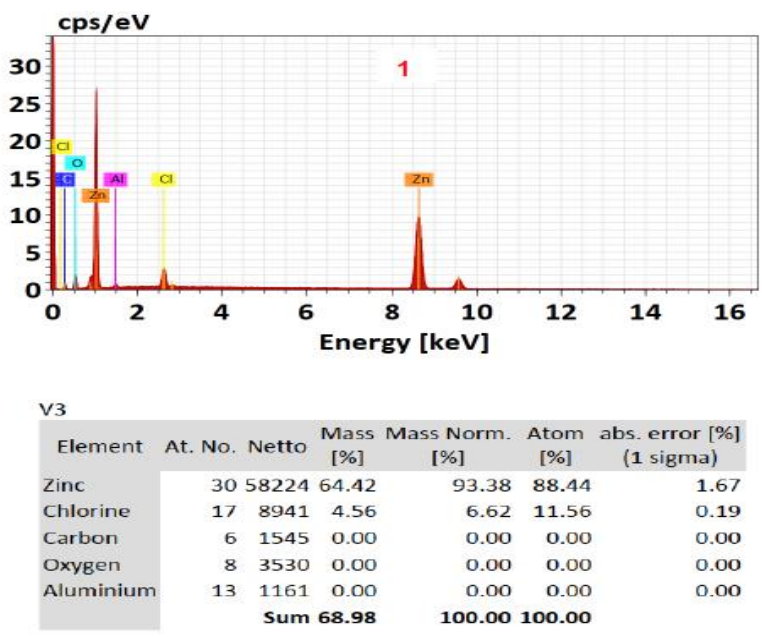

(b)

Figure 2. SEM (a) and EDS (b) images of the oxidized fraction.

\section{Results and Discussion}

3.1. Thermodynamic Analysis of the Reactions of Chlorination of Zinc, Impurity Metals and Their Oxides with Calcium and Ammonium Chlorides

The model of thermodynamic reactions of chlorination of the components of the metal fraction with ammonium chloride (melting) and the oxidized fraction of dross (roasting) with calcium and ammonium chloride is considered from the standpoint of the above results of mineralogical studies of the phase composition of the initial products. The mechanism of the chlorination process can be described by a system of reactions typical for the conditions of melting the metal fraction of dross with ammonium chloride and roasting the oxidized fraction with $\mathrm{CaCl}_{2}$ and $\mathrm{NH}_{4} \mathrm{Cl}$, shown in Table 3.

Table 3. Calculated values of the Gibbs free energy of the reactions of chlorination of zinc, impurity metals and their oxides with calcium and ammonium chlorides.

\begin{tabular}{|c|c|c|c|c|c|c|c|c|c|}
\hline \multirow{3}{*}{$\#$} & \multirow{3}{*}{ Reactions } & \multicolumn{8}{|c|}{ Temperature, $\mathrm{K}$} \\
\hline & & 673 & 773 & 873 & 973 & 1073 & 1173 & 1273 & 1373 \\
\hline & & \multicolumn{8}{|c|}{$\Delta G^{\circ}{ }_{T}, \mathrm{~kJ} / \mathrm{mol}$} \\
\hline (1) & $\begin{array}{l}\mathrm{Zn}+\mathrm{CaCl}_{2}+0.5 \mathrm{O}_{2}= \\
\quad=\mathrm{ZnCl}_{2}+\mathrm{CaO}\end{array}$ & -189.1 & -180.6 & -172.21 & -164.07 & -155.4 & -144.8 & -134.2 & -123.7 \\
\hline (2) & $\mathrm{ZnCl}_{2}+0.5 \mathrm{O}_{2}=\mathrm{ZnO}+\mathrm{Cl}_{2}$ & 31.5 & 28.9 & 26.7 & 24.8 & 23.2 & 21.9 & 20.8 & 19.9 \\
\hline (3) & $\begin{array}{c}\mathrm{Pb}+\mathrm{CaCl}_{2}+0.5 \mathrm{O}_{2(\mathrm{~g})}= \\
=\mathrm{PbCl}_{2}+\mathrm{CaO}\end{array}$ & -67.6 & -74.5 & -81.2 & -87.9 & -93.6 & -97.2 & -100.5 & -103.6 \\
\hline (4) & $\begin{array}{c}\mathrm{Fe}+1.5 \mathrm{CaCl}_{2}+0.75 \mathrm{O}_{2(\mathrm{~g})}= \\
\mathrm{FeCl}_{3}+1.5 \mathrm{CaO}\end{array}$ & -65.4 & -51.9 & -38.5 & -25.2 & -10.6 & 7.3 & 25.4 & 43.7 \\
\hline (5) & $\begin{array}{c}\mathrm{Cu}+\mathrm{CaCl}_{2}+0.5 \mathrm{O}_{2(\mathrm{~g})}= \\
\quad=\mathrm{CuCl}_{2}+\mathrm{CaO}\end{array}$ & 3.7 & 11.4 & 18.7 & 25.7 & 33.1 & 42.1 & 50.9 & 59.7 \\
\hline (6) & $\begin{array}{c}\mathrm{Ni}+\mathrm{CaCl}_{2}+0.5 \mathrm{O}_{2(\mathrm{~g})}= \\
=\mathrm{NiCl}_{2}+\mathrm{CaO}\end{array}$ & -77 & -67.03 & -57.14 & -47.32 & -36.78 & -24.21 & -11.54 & -2.96 \\
\hline (7) & $\begin{aligned} \mathrm{Cd} & +\mathrm{CaCl}_{2}+0.5 \mathrm{O}_{2(\mathrm{~g})}= \\
& =\mathrm{CdCl}_{2}+\mathrm{CaO}\end{aligned}$ & -160.51 & -150.58 & -142.33 & -136.94 & -131.1 & -123.5 & -116 & -108.65 \\
\hline (8) & $\begin{array}{c}\mathrm{ZnCl}_{2}+\mathrm{Pb}+0.5 \mathrm{O}_{2(\mathrm{~g})}= \\
=\mathrm{PbCl}_{2}+\mathrm{ZnO}\end{array}$ & -162.04 & -166.86 & -171.3 & -175.4 & -179.2 & -182.7 & -186 & -189.2 \\
\hline (9) & $\begin{array}{l}3 \mathrm{ZnCl}_{2}+2 \mathrm{Fe}+1.5 \mathrm{O}_{2(\mathrm{~g})}= \\
\quad=2 \mathrm{FeCl}_{3}+3 \mathrm{ZnO}\end{array}$ & -414.1 & -380.91 & -347.16 & -312.95 & -277.9 & -242 & -205.7 & -136.26 \\
\hline
\end{tabular}


Table 3. Cont.

\begin{tabular}{|c|c|c|c|c|c|c|c|c|c|}
\hline \multirow{3}{*}{$\#$} & \multirow{3}{*}{ Reactions } & \multicolumn{8}{|c|}{ Temperature, K } \\
\hline & & 673 & 773 & 873 & 973 & 1073 & 1173 & 1273 & 1373 \\
\hline & & \multicolumn{8}{|c|}{$\Delta G^{\circ} T, \mathrm{~kJ} / \mathrm{mol}$} \\
\hline (10) & $\begin{array}{l}\mathrm{ZnCl}_{2}+\mathrm{Cu}+0.5 \mathrm{O}_{2(\mathrm{~g})}= \\
\quad=\mathrm{CuCl}_{2}+\mathrm{ZnO}\end{array}$ & -90.7 & -80.9 & -71.23 & -61.73 & -52.43 & -43.36 & -34.55 & -25.84 \\
\hline (11) & $\begin{array}{l}\mathrm{ZnCl}{ }_{2}+\mathrm{Ni}+0.5 \mathrm{O}_{2(\mathrm{~g})}= \\
\quad=\mathrm{NiCl}_{2}+\mathrm{ZnO}\end{array}$ & -171.42 & -159.39 & -147.18 & -134.81 & -122.3 & -109.7 & -97.09 & -88.53 \\
\hline (12) & $\begin{array}{c}\mathrm{ZnCl}_{2}+\mathrm{Cd}+0.5 \mathrm{O}_{2(\mathrm{~g})}= \\
\quad=\mathrm{CdCl}_{2}+\mathrm{ZnO}\end{array}$ & -254.93 & -242.93 & -232.36 & -224.44 & -216.6 & -209 & -201.5 & -194.23 \\
\hline (13) & $\begin{array}{c}\mathrm{Zn}+2 \mathrm{NH}_{4} \mathrm{Cl}+0.5 \mathrm{O}_{2(\mathrm{~g})}= \\
=\mathrm{ZnCl}_{2}+2 \mathrm{NH}_{3(\mathrm{~g})}+\mathrm{H}_{2} \mathrm{O}_{(\mathrm{g})}\end{array}$ & -249.52 & -279.21 & -309.16 & -339.55 & -370.3 & -401.6 & -433.2 & -465.27 \\
\hline (14) & $\begin{array}{l}\mathrm{ZnO}+2 \mathrm{NH}_{4} \mathrm{Cl}=\mathrm{ZnCl}_{2}+ \\
\quad+2 \mathrm{NH}_{3(\mathrm{~g})}+\mathrm{H}_{2} \mathrm{O}_{(\mathrm{g})}\end{array}$ & -81.99 & -133.48 & -186.03 & -239.54 & -293.9 & -349.1 & -405 & -461.67 \\
\hline (15) & $\begin{array}{c}\mathrm{Pb}+2 \mathrm{NH}_{4} \mathrm{Cl}+0.5 \mathrm{O}_{2(\mathrm{~g})}= \\
=\mathrm{PbCl}_{2}+2 \mathrm{NH}_{3(\mathrm{~g})}+\mathrm{H}_{2} \mathrm{O}_{(\mathrm{g})}\end{array}$ & -244.03 & -300.35 & -357.33 & -414.94 & -473.1 & -531.8 & -591.1 & -650.87 \\
\hline (16) & $\begin{array}{c}\mathrm{Fe}+3 \mathrm{NH}_{4} \mathrm{Cl}+0.75 \mathrm{O}_{2(\mathrm{~g})}= \\
=\mathrm{FeCl}_{3}+3 \mathrm{NH}_{3(\mathrm{~g})}+ \\
+1.5 \mathrm{H}_{2} \mathrm{O}_{(\mathrm{g})}\end{array}$ & -330.04 & -390.68 & -452.63 & -515.79 & -579.8 & -644.6 & -710.4 & -777.13 \\
\hline (17) & $\begin{array}{c}\mathrm{Cu}+2 \mathrm{NH}_{4} \mathrm{Cl}+0.5 \mathrm{O}_{2(\mathrm{~g})}= \\
=\mathrm{CuCl}_{2}+2 \mathrm{NH}_{3(\mathrm{~g})}+\mathrm{H}_{2} \mathrm{O}_{(\mathrm{g})}\end{array}$ & -172.7 & -214.39 & -257.27 & -301.28 & -346.3 & -392.4 & -439.5 & -487.51 \\
\hline (18) & $\begin{array}{c}\mathrm{Ni}+2 \mathrm{NH}_{4} \mathrm{Cl}+0.5 \mathrm{O}_{2(\mathrm{~g})}= \\
=\mathrm{NiCl}_{2}+2 \mathrm{NH}_{3(\mathrm{~g})}+\mathrm{H}_{2} \mathrm{O}_{(\mathrm{g})}\end{array}$ & -253.42 & -292.88 & -333.21 & -374.36 & -416.2 & -458.8 & -502.1 & -550.21 \\
\hline (19) & $\begin{array}{c}\mathrm{Cd}+2 \mathrm{NH}_{4} \mathrm{Cl}+0.5 \mathrm{O}_{2(\mathrm{~g})}= \\
=\mathrm{CdCl}_{2}+2 \mathrm{NH}_{3(\mathrm{~g})}+\mathrm{H}_{2} \mathrm{O}_{(\mathrm{g})}\end{array}$ & -336.93 & -376.42 & -418.4 & -463.9 & -510.5 & -558.1 & -606.6 & -655.9 \\
\hline (20) & $\begin{array}{c}\mathrm{PbO}+2 \mathrm{NH}_{4} \mathrm{Cl}=\mathrm{PbCl}_{2}+ \\
+2 \mathrm{NH}_{3(\mathrm{~g})}+\mathrm{H}_{2} \mathrm{O}_{(\mathrm{g})}\end{array}$ & -157.17 & -206.56 & -259.76 & -314.03 & -369.2 & -425 & -479.6 & -534.97 \\
\hline (21) & $\begin{array}{c}\mathrm{Fe}_{2} \mathrm{O}_{3}+6 \mathrm{NH}_{4} \mathrm{Cl}=2 \mathrm{FeCl}_{3}+ \\
+6 \mathrm{NH}_{3(\mathrm{~g})}+3 \mathrm{H}_{2} \mathrm{O}_{(\mathrm{g})}\end{array}$ & -24.53 & -173.18 & -324.18 & -477.23 & -632.2 & -789.2 & -948.1 & -1108.8 \\
\hline (22) & $\begin{array}{l}\mathrm{CuO}+2 \mathrm{NH}_{4} \mathrm{Cl}=\mathrm{CuCl}_{2}+ \\
+2 \mathrm{NH}_{3(\mathrm{~g})}+\mathrm{H}_{2} \mathrm{O}_{(\mathrm{g})}\end{array}$ & -78.92 & -129.27 & -180.67 & -233.07 & -286.4 & -340.6 & -395.7 & -451.75 \\
\hline (23) & $\begin{array}{l}\mathrm{NiO}+2 \mathrm{NH}_{4} \mathrm{Cl}=\mathrm{NiCl}_{2}+ \\
\quad+2 \mathrm{NH}_{3(\mathrm{~g})}+\mathrm{H}_{2} \mathrm{O}_{(\mathrm{g})}\end{array}$ & -74.82 & -122.97 & -171.92 & -221.62 & -272 & -323 & -374.7 & -431.15 \\
\hline (24) & $\begin{array}{l}\mathrm{CdO}+2 \mathrm{NH}_{4} \mathrm{Cl}=\mathrm{CdCl}_{2}+ \\
\quad+2 \mathrm{NH}_{3(\mathrm{~g})}+\mathrm{H}_{2} \mathrm{O}_{(\mathrm{g})}\end{array}$ & -144.47 & -194.53 & -247 & -302.99 & -359.9 & -417.7 & -476.4 & -535.83 \\
\hline
\end{tabular}

The probable direction of the reactions was estimated by the change in the thermodynamic values of the system. Thermodynamic calculations were conducted by calculating the Gibbs free energy $\left(\Delta \mathrm{G}^{\circ} \mathrm{T}\right)$ of reactions and establishing their dependence on temperature. As the standard state of zinc, impurities metals and their oxides, the pure solid metal $\left(\mathrm{Me}_{\mathrm{s}}\right.$.) and solid oxide $\left(\mathrm{MeO}_{\mathrm{s}}\right.$.) was taken. For metal chlorides, the pure $\mathrm{MeCl}_{2(\mathrm{~g})}$ was considered. For the calculations, the reference data from [22] and the NIST-JANAF Thermochemical Tables website (http:/ / kinetics.nist.gov/janaf, accessed on 20 September 2021) were used. The results of thermodynamic calculations are summarized in Table 3.

It was found that the course of interaction reactions between metal oxides $\mathrm{MeO}$ $\left(\mathrm{Me}-\mathrm{Zn}, \mathrm{Pb}, \mathrm{Fe}, \mathrm{Cu}, \mathrm{Ni}, \mathrm{Cd}\right.$ ) and $\mathrm{CaCl}_{2}$ in the entire investigated temperature range is impossible due to the positive values of the Gibbs free energy. During the roasting, active chlorination of metallic zinc with calcium chloride according to reaction (1) is expected. In the temperature range $673-1373 \mathrm{~K}$, the Gibbs free energy of reaction (1) shows a decrease with increasing temperature: from $\Delta \mathrm{G}_{673 \mathrm{~K}}=-189.1 \mathrm{~kJ} / \mathrm{mol}$ to $\Delta \mathrm{G}_{1373 \mathrm{~K}}=-123.7 \mathrm{~kJ} / \mathrm{mol}$. Nevertheless, the high negative values of the Gibbs free energy indicate the possibility of the formation of gaseous zinc chloride and solid calcium oxide in the cinder over the entire investigated temperature range.

Zinc chloride formed as a result of reaction (1) does not interact with atmospheric oxygen according to reaction (2) due to the positive values of Gibbs free energy in the 
entire investigated temperature range of $673-1373 \mathrm{~K}$. Thus, it can be argued that, under conditions of joint roasting of the oxide fraction of dross with $\mathrm{CaCl}_{2}$ in an oxidizing atmosphere, favorable conditions are created for the conversion of metallic zinc into oxide. From a practical point of view, this will lead to an increase in the content of zinc oxide and, as a result, improve the quality of the final product $(\mathrm{ZnO})$.

For the melting of the metal fraction, the use of calcium chloride does not seem to be effective due to the favorable conditions being created for the conversion of metallic zinc into its oxide. This will have a significant effect on reducing the quality of the resulting metal zinc ingot. The interaction of impurity metals with $\mathrm{CaCl}_{2}$ is described by a group of reactions (3)-(7). At the temperature of melting $(673 \mathrm{~K})$ and roasting $(1373 \mathrm{~K})$, all reactions, except for reaction (5), are characterized by negative values of Gibbs free energy. High negative values of $\Delta \mathrm{G}_{\mathrm{T}}^{\mathrm{o}}$ are typical for reactions (3), (6) and (7), which indicates a deep sublimation of lead, nickel and cadmium, both during the melting of the metal fraction and during the roasting of the oxidized fraction.

Under roasting conditions, the possibility of the interaction of impurity metals with zinc chloride formed by reaction (1) is not excluded. The mechanism of the interaction of impurity metals with $\mathrm{ZnCl}_{2}$ is described by the course of reactions (8)-(12). The results of thermodynamic calculations show large negative values of the Gibbs free energy of reactions (8)-(12). The high probability of reactions (8)-(12) indicates their priority over reactions (2), (3)-(7), which describe the direct chlorination of impurity metals with calcium chloride. The course of reactions (8)-(12) creates favorable conditions for the deep sublimation of impurity metals in the form of their chlorides, which significantly affects the improvement of the quality of the resulting zinc oxide.

The mechanism of roasting of oxide fraction of dross with ammonium chloride (Table 3) is described by a group of reactions (13)-(24). Large negative values of the Gibbs free energy of reactions (13)-(24) show a high probability of their occurrence and contribute to the production of purer zinc oxide due to the deep sublimation of impurity metals in the form of their chlorides. The values of the Gibbs free energy of reactions (13)-(24) are much higher than the values of $\Delta \mathrm{G}^{\circ} \mathrm{T}$ for reactions (3)-(7) (Table 3).

The obtained results indicate the preference and higher efficiency of melting the metal fraction of dross with ammonium chloride than with calcium chloride. The choice and justification of one or another chlorinating reagent for each specific process (melting, roasting) should be determined on the basis of the results of experimental tests, to study the effect of their consumption on the sublimation depth of impurity metals from both the metal fraction of the dross and the oxidized fraction.

\subsection{Melting of Metal Fraction of Dross with Ammonium Chloride Addition}

The initial sample in the amount of $50 \mathrm{~g}$, prepared by mixing three large metal fractions of zinc (Table 1), was melted in a shaft silite furnace. Impurity content in the averaged sample: $\mathrm{Pb}-0.8 \%, \mathrm{Fe}-0.22 \%, \mathrm{Cu}-0.15 \%, \mathrm{Cd}-0.005 \%$. Previously, $\mathrm{NH}_{4} \mathrm{Cl}$ was added to the initial sample in an amount of $2 \%$ of the sample weight. Melting was carried out at a temperature of $450{ }^{\circ} \mathrm{C}$ in an inert gas (Ar) atmosphere with a flow rate of $0.21 / \mathrm{min}$. The duration of the experiments was $60 \mathrm{~min}$.

After melting, an ingot of metallic zinc was obtained. The results of SEM and EDS analysis of the metal zinc ingot obtained after melting (Figure 3) showed the presence of exclusively zinc in it, which confirms its high quality.

\subsection{Roasting of Oxidized Dross Fraction with $\mathrm{CaCl}_{2}$ and $\mathrm{NH}_{4} \mathrm{Cl}$}

The scheme of the installation for studying the influence of the consumption of chlorinating reagents $\left(\mathrm{CaCl}_{2}, \mathrm{NH}_{4} \mathrm{Cl}\right)$ and temperature on the production of commercial zinc oxide, suitable for use as mineral additives in animal and poultry feed, is shown in Figure 4. 


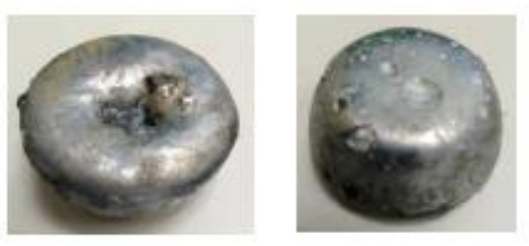

a)

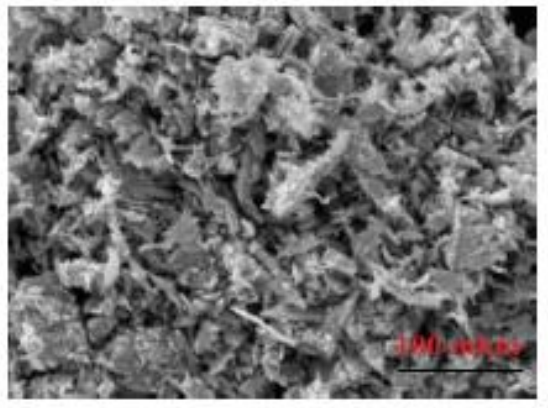

b)

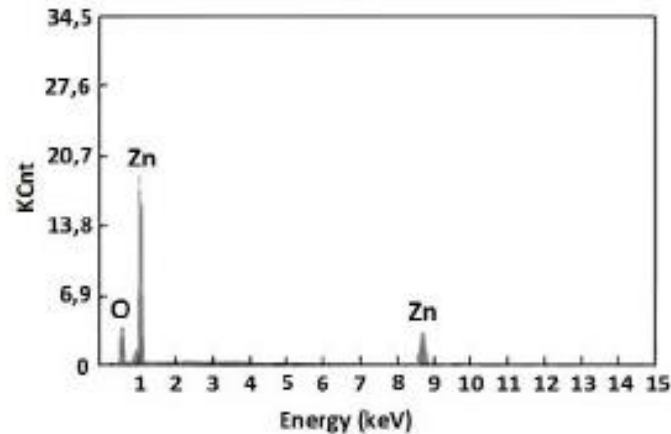

c)

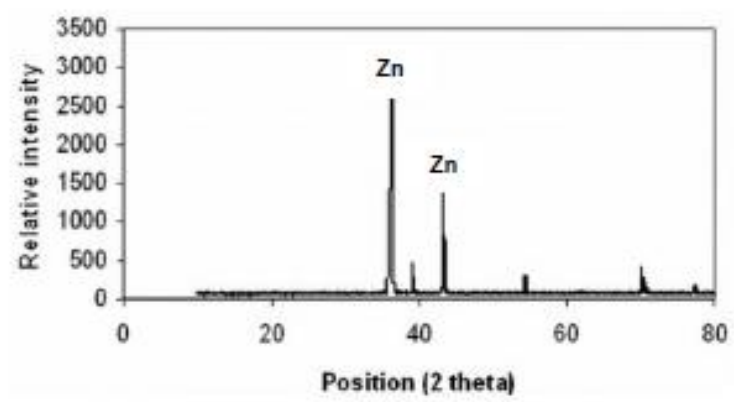

d)

Figure 3. SEM (b), EDS (c) and XRD (d) results of metal zinc ingot (a).

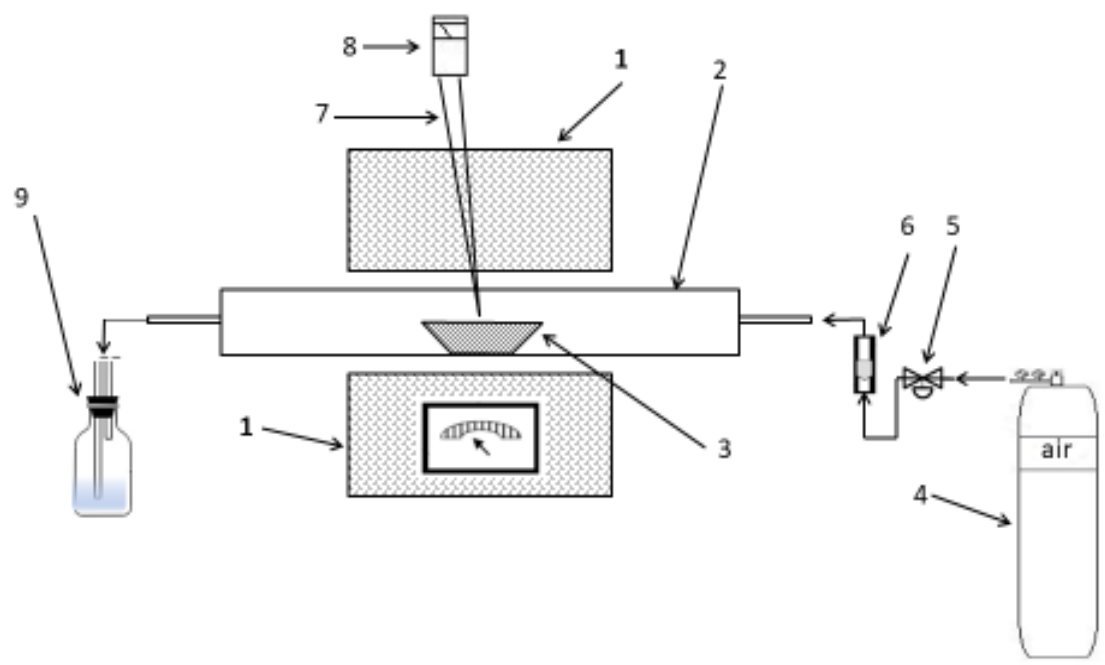

Figure 4. Laboratory setup scheme. 1-Nabertherm R50/250/12 electric furnace with temperature controller B410; 2-quartz reactor; 3-alundum boat with sample; 4-air cylinder; 5-valve; 6rotameter RM-GC/0,04; 7-thermocouple type R; 8-secondary device KSP-4; 9-gas-cleaning bottle.

The experiments were carried out according to the method described above. The oxide fraction of the dross after hot galvanizing was mixed with a given consumption of calcium chloride and ammonium chloride in various mass ratios. The mixture was held in an alumina crucible inside the furnace, which was heated and then held at a predetermined temperature in an air flow that was supplied at a rate of $100 \mathrm{~mL} / \mathrm{min}$. Off-gases from the furnace were absorbed in a gas absorption vessel. After settling and cooling in a stream of air, the crucible was removed from the furnace and broken. The final product (cinder) was weighed and analyzed in accordance with the methods described above. 
In the first series of experiments, the influence of the consumption of each separately taken chlorinating reagent $\left(\mathrm{CaCl}_{2}, \mathrm{NH}_{4} \mathrm{Cl}\right)$ on the degree of sublimation of impurities was studied. In all experiments, the temperature was constant and amounted to $1000{ }^{\circ} \mathrm{C}$. The dependence of the final content of impurity metals in the cinder obtained after roasting on the consumption of $\mathrm{CaCl}_{2}$ and $\mathrm{NH}_{4} \mathrm{Cl}$ is shown in Figure 5 .

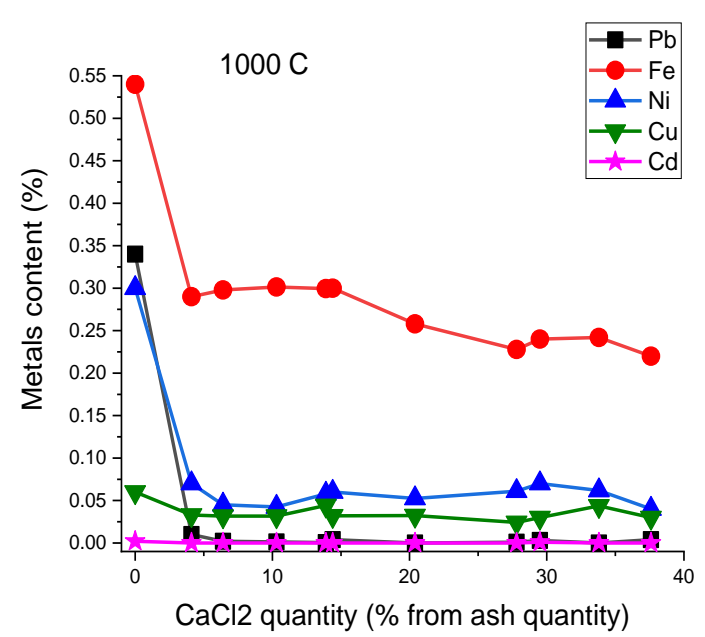

(a)

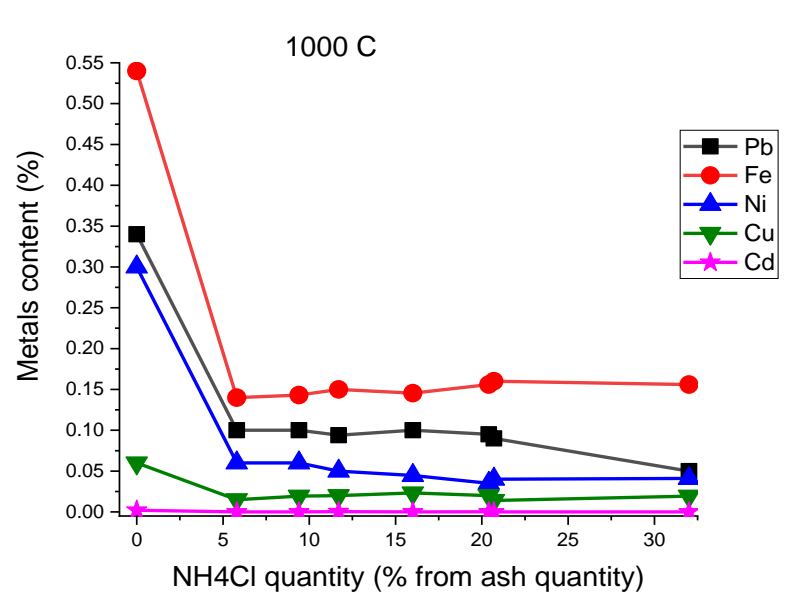

(b)

Figure 5. Dependence of the content of metal impurities on the consumption of $\mathrm{CaCl}_{2}(\mathbf{a})$ and $\mathrm{NH}_{4} \mathrm{Cl}(\mathbf{b})$.

Comparative analysis of the results shown in Figure 5 indicates that an increase in the consumption of both $\mathrm{CaCl}_{2}$ and $\mathrm{NH}_{4} \mathrm{Cl}$ has a strong effect on reducing the content of all metal impurities in the final product (cinder). In the case of roasting the oxidized dross fraction jointly with $\mathrm{CaCl}_{2}$, the effect of $\mathrm{CaCl}_{2}$ consumption on the iron content is insignificant (Figure 5a). In the range of $\mathrm{CaCl}_{2}$ consumption from 6 to $37 \%$ of the weight of the feed material, the iron content in the cinder decreases slightly, from 0.3 to $0.25 \%$. At the same time, the content of lead and other impurity metals shows a sharp decrease, even at low consumption of $\mathrm{CaCl}_{2}$. As can be seen in Figure $5 \mathrm{a}$, the addition of $\mathrm{CaCl}_{2}$ to the initial sample in an amount of $6 \%$ of its weight provides a minimum lead content of $0.002 \%$ in the final cinder. A further increase in the consumption of $\mathrm{CaCl}_{2}$ has no effect on the decrease in the lead content in the cinder. This tendency is typical for copper, nickel and cadmium: at a $\mathrm{CaCl}_{2}$ consumption equal to $6 \%$ of the weight of the feed material, the minimum contents of copper, nickel and cadmium in the cinder are achieved, which remain practically at the same level regardless of the increase in the $\mathrm{CaCl}_{2}$ consumption.

Roasting the oxidized dross fraction with the addition of $\mathrm{NH}_{4} \mathrm{Cl}$ provides a minimum iron content of up to $0.15 \%$ in the final cinder (Figure $5 b$ ). At the same time, the general character of the curve of the dependence of the content of impurity metals $(\mathrm{Cu}, \mathrm{Ni}, \mathrm{Cd})$ on the $\mathrm{NH}_{4} \mathrm{Cl}$ consumption (in the range of variation in the consumption from 5 to $37 \%$ of the weight of the initial material), repeats the course of the curve of a similar dependence established for impurity metals in the case of roasting using $\mathrm{CaCl}_{2}$ (Figure $5 \mathrm{a}$ ). Figure $5 \mathrm{~b}$ shows that the consumption of $\mathrm{NH}_{4} \mathrm{Cl}$ from 5 to $20 \%$ by weight of the feed material has no significant effect on the lead content in the resulting cinder. At low consumption of $\mathrm{NH}_{4} \mathrm{Cl}$ $(5 \%)$, although a sharp decrease in the lead content from 0.55 in the initial material to $0.12 \%$ is achieved, a further increase in the consumption has only a slight decrease in it in the cinder. It was found that the optimal consumption of $\mathrm{NH}_{4} \mathrm{Cl}$, providing a simultaneous minimum value of all metal impurities, corresponds to the consumption of $\mathrm{NH}_{4} \mathrm{Cl}$, equal to $15 \%$ of the weight of the feed material. This achieves a minimum lead content $(0.1 \%)$ in the cinder.

The obtained results fully confirm the data of thermodynamic analysis and show that the use of $\mathrm{CaCl}_{2}$ and $\mathrm{NH}_{4} \mathrm{Cl}$ as a chlorinating reagent provides a deep purification of the 
initial material from such impurities as $\mathrm{Pb}, \mathrm{Cu}, \mathrm{Ni}$ and $\mathrm{Cd}$. The best solution seems to be the simultaneous use of $\mathrm{CaCl}_{2}$ and $\mathrm{NH}_{4} \mathrm{Cl}$. As the results of the experiments show, the optimal composition of the mixture, consisting of $\mathrm{CaCl}_{2}$ and $\mathrm{NH}_{4} \mathrm{Cl}$, corresponds to consumption: $6 \% \mathrm{CaCl}_{2}$ and $15 \% \mathrm{NH}_{4} \mathrm{Cl}$ by weight of the feed material. Figure 6 shows the results of studying the effect of the roasting temperature of the oxidized dross fraction on the sublimation of impurity metals using a mixture of $\mathrm{CaCl}_{2}$ and $\mathrm{NH}_{4} \mathrm{Cl}$ with their consumption equal to 6 and 15\% of the weight of the feed material, respectively.

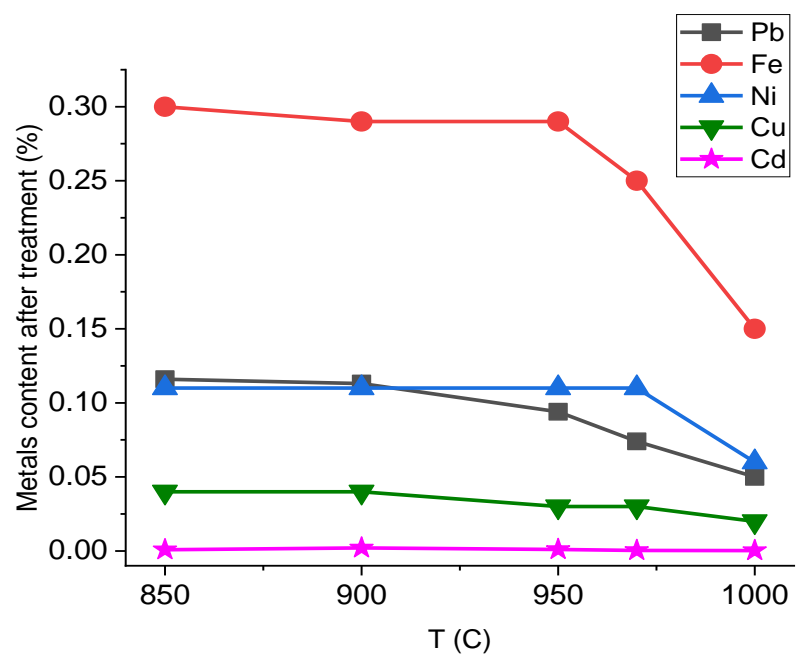

Figure 6. Dependence of the content of metal impurities on temperature. Consumption of $\mathrm{CaCl}_{2} 6 \%$ and $\mathrm{NH}_{4} \mathrm{Cl} 15 \%$, by weight of the feed material.

It was found that the active removal of metal impurities from the cinder is observed in the temperature range $950-1000{ }^{\circ} \mathrm{C}$. The best results were achieved at a roasting temperature of $1000{ }^{\circ} \mathrm{C}$ : the degree of sublimation of copper, nickel and iron chlorides is $\sim 75 \%$ and lead and cadmium are $90-98 \%$ of their initial amount in the dross. Composition of the obtained cinder (wt.\%) is $0.05 \mathrm{~Pb}, 0.15 \mathrm{Fe}, 0.06 \mathrm{Ni}, 0.003 \mathrm{Cu}$ and $0.001 \mathrm{Cd}$, and fully complies with the requirements for pure zinc oxide used as mineral additives in animal and poultry feed.

\section{Conclusions}

This article presents a new method for obtaining pure metallic zinc and zinc oxide from hot-dip galvanizing dross by chlorination of a previously separated oxidized and non-metallic fraction. It was estimated that treatment of one ton of steel generates about $10 \mathrm{~kg}$ of the zinc dross and $9 \mathrm{~kg}$ of the zinc ash, giving a potential total zinc stream of $15-18 \mathrm{~kg}$ to recover. The results of thermodynamic calculations have shown that the use of $\mathrm{CaCl}_{2}$ and $\mathrm{NH}_{4} \mathrm{Cl}$ as chlorinating reagents makes it possible to obtain commercial metallic zinc and pure zinc oxide by deep reduction of impurity metals $(\mathrm{Pb}, \mathrm{Fe}, \mathrm{Cu}, \mathrm{Ni}, \mathrm{Cd})$.

It was found that the greatest effect is achieved when melting the metal fraction with ammonium chloride. The mechanism of the process is described, and the optimal melting parameters are established, which ensure the production of a pure metal ingot of zinc: $\mathrm{NH}_{4} \mathrm{Cl}$ consumption $-2 \%$ by weight of the feed material, $\mathrm{T}=450{ }^{\circ} \mathrm{C}$, melting duration$60 \mathrm{~min}$. The results were obtained on the influence of $\mathrm{CaCl}_{2}$ and $\mathrm{NH}_{4} \mathrm{Cl}$ consumption on the degree of sublimation of impurity metals under roasting conditions at a temperature of $1000{ }^{\circ} \mathrm{C}$. It was found that the use of $\mathrm{CaCl}_{2}$ as a chlorinating reagent provides deep purification of the feed material from impurities such as $\mathrm{Pb}, \mathrm{Cu}, \mathrm{Ni}$ and $\mathrm{Cd}$. At the same time, the maximum reduction in the iron content is not possible. It is shown that the use of $\mathrm{NH}_{4} \mathrm{Cl}$ as a chlorinating reagent, although it provides deep removal of impurity metals, does not succeed in reducing the lead content: the lead content in the cinder remains at the level of $0.12 \%$. 
The best solution seems to be the simultaneous use of $\mathrm{CaCl}_{2}$ and $\mathrm{NH}_{4} \mathrm{Cl}$. As the results of the experiments show, the optimal composition of the mixture, consisting of $\mathrm{CaCl}_{2}$ and $\mathrm{NH}_{4} \mathrm{Cl}$, should correspond to the consumption of $6 \% \mathrm{CaCl}_{2}$ and $15 \% \mathrm{NH}_{4} \mathrm{Cl}$ by weight of the feed material. The optimal parameters of roasting were established as: $\mathrm{T}=1000{ }^{\circ} \mathrm{C}$, duration-60 $\mathrm{min}$, air consumption- $0.1 \mathrm{l} / \mathrm{min}$. Technological indicators of the process: composition of the obtained pure zinc oxide ( $\mathrm{wt} \%$ ): $0.05 \mathrm{~Pb}, 0.15 \mathrm{Fe}, 0.06 \mathrm{Ni}, 0.003 \mathrm{Cu}$ and $0.001 \mathrm{Cd}$; the degree of sublimation of chlorides of copper, nickel and iron $\sim 75 \%$ and lead and cadmium $90-98 \%$ of their initial amount in the dross.

Author Contributions: Conceptualization, N.K.D. and V.K.; methodology, E.E.Z.; software, G.M.K.; validation, A.K., Y.B.T. and A.A.; formal analysis, Y.I.K.; investigation, A.A.; resources, N.K.D.; data curation, G.M.K.; writing—original draft preparation, A.A.; writing-review and editing, V.K.; visualization, N.K; supervision, G.M.K.; project administration, N.K.D.; funding acquisition, G.M.K. All authors have read and agreed to the published version of the manuscript.

Funding: This study received funding from the Science Committee of the Ministry of Education and Science of the Republic of Kazakhstan, project No. AP09058297 “Development of a new waste-free technology for the disposal of hot-dip galvanizing waste with complex extraction of valuable components".

Institutional Review Board Statement: Not applicable.

Informed Consent Statement: Not applicable.

Data Availability Statement: The references were presented in the text of the manuscript.

Acknowledgments: The research was carried out within the framework of grant funding of the Science Committee of the Ministry of Education and Science of the Republic of Kazakhstan for 2021-2023 in the priority area "Rational use of natural resources, including water resources, geology, processing, new materials and technologies, safe products and structures" project No. AP09058297, "Development of a new waste-free technology for the disposal of hot-dip galvanized wastes with complex extraction of valuable components".

Conflicts of Interest: On behalf of all authors, the corresponding author declares that there is no conflict of interest.

\section{References}

1. Saramak, D.; Krawczykowski, D.; Gawenda, T. Investigations of zinc recovery from metallurgical waste. IOP Conf. Ser.: Mater. Sci. Eng. 2018, 427, 012017. [CrossRef]

2. Trpcevska, J.; Rudnik, E.; Holkova, B.; Laubertova, M. Leaching of Zinc Ash with Hydrochloric Acid Solutions. Pol. J. Environ. Stud. 2018, 27, 1771-1785. [CrossRef]

3. Stubbe, G.; Hillmann, C.; Wolf, C. Zinc and Iron Recovery from Filter Dust by Melt Bath Injection into an Induction Furnace. Erzmetall 2016, 69, 5-12.

4. Konstantinov, V.M.; Gegenya, D.V.; Bogdanchik, M.I. Market overview for zinc and zinc waste. In Foundry Processes; MSTU: Russia, Moskow, 2014; 293p.

5. Takácová, Z.; Hluchánová, B.; Trpcevská, J. Leaching of zinc from zinc ash originating from hot-dip galvanizing. Metall 2010, 64, 517-519.

6. Schmitz, D.; Friedrich, B. In-house recycling of hard zinc and zinc ash by liquid metal centrifugation. In Proceedings of the EMC; GDMB: Düsseldorf, Germany, 2007; pp. 1-20.

7. Smakowski, T.; Galos, K.; Lewicka, E. Balance of Management of Mineral Resources of Poland and the World 2013; Panstwowy Instytut Geologiczny: Warszawa, Poland, 2013.

8. QYR Steel Research Center. Global Hot-Dip Galvanized Steel Market Insights, Forecast to 2025; QYR Steel Research Center: Beijing, China, 2019. Available online: https:/ / www.reportsnreports.com/reports/1821020-global-hot-dip-galvanized-steel-marketinsights-forecast-to-2025.html (accessed on 1 September 2021).

9. Najiba, S. Recovery of Zinc from Ash of Galvanizing Plant by Hydrometallurgical Route. Master's Thesis, Bangladesh University of Engineering and Technology, Dhaka, Bangladesh, 2009; pp. 1-92.

10. Yagubova, V.L.; Chumaevsky, O.V. Method for Producing Zinc Nitrate. RF Patent No. 96111199/25, 4 October 1998.

11. Barkhatov, V.I.; Dobrovolsky, I.P.; Kapkaev, Y.S.; Kostyunin, S.V. Method for Processing Waste Containing Heavy Non-Ferrous Metals. RF Patent No. 2016108776, 26 May 2017.

12. Kazantsev, G.F.; Barbin, N.M.; Moiseev, G.K.; Vatolin, N.A. Method for Processing Zinc Waste. RF Patent No. 99107789/02, 4 October 2000 . 
13. Chernov, P.P.; Koryshev, A.N.; Larin, Y.I. Method for Producing Zinc from Zinc Dross. RF Patent No. 2001109810/02, 27 August 2002.

14. Yudin, R.A.; Vinogradov, A.V.; Kovryakov, S.V.; Sudakov, E.A.; Yanichev, A.N. Installation and Method of Extracting Zinc from Zinc Ash. RF Patent No. 2008102795/02, 10 October 2009.

15. Kodochigov, B.N. Method for Processing Zinc Ash. RF Patent No. 2267546, 10 January 2006.

16. Tarasov, A.V. Recycling of Hot-Dip Galvanized Waste. Steel 1989, 6, 57-58.

17. Wang, H.; Feng, Y.; Li, H.; Kang, J. The separation of gold and vanadium in carbonaceous gold ore by one-step roasting method. Powder Technol. 2019, 355, 191. [CrossRef]

18. Wang, H.; Feng, Y.; Li, H.; Kang, J. Simultaneous extraction of gold and zinc from refractory carbonaceous gold ore by chlorination roasting process. Trans. Nonferrous Met. Soc. China 2020, 30, 1111. [CrossRef]

19. Guo, X.; Zhang, B.; Wang, Q.; Li, Z.; Tian, Q. Recovery of Zinc and Lead from Copper Smelting Slags by Chlorination Roasting. JOM 2021, 73, 1861-1870. [CrossRef]

20. Bai, S.; Bi, Y.; Ding, Z.; Li, C.; Wen, S. Innovative methodology for the utilization of low-grade pyrite cinder containing heavy metals via hydrothermal alkali melting followed by chlorination roasting. J. Alloys Compd. 2020, 840, 155722. [CrossRef]

21. Qin, H.; Guo, X.; Tian, Q.; Zhang, L. Pyrite enhanced chlorination roasting and its efficacy in gold and silver recovery from gold tailing. Sep. Purif. Technol. 2020, 250, 117168. [CrossRef]

22. Turkdogan, E.T. Physical Chemistry of High Temperature Technology; Academic Press: New York, NY, USA, 1980; 462p. 